\title{
Contribution of MRI to clinically equivocal penile fracture cases
}

\author{
Rüştü Türkay, M.D., ${ }^{1}$ Mustafa Gürkan Yenice, M.D., ${ }^{2}$ Sema Aksoy, M.D.,, Gökhan Şeker, M.D., ${ }^{2}$ \\ Selçuk Şahin, M.D., ${ }^{2}$ Ercan İnci, M.D., ${ }^{1}$ Volkan Tuğcu, M.D., ${ }^{2}$ Ali İhsan Taşcl, M.D. ${ }^{2}$
}

${ }^{1}$ Department of Radiology, İstanbul Dr. Sadi Konuk Training and Research Hospital, İstanbul-Turkey

${ }^{2}$ Department of Urology, İstanbul Dr. Sadi Konuk Training and Research Hospital, İstanbul-Turkey

\begin{abstract}
BACKGROUND: Penile fracture is a surgical emergency defined as rupture of the tunica albuginea. Although most cases can be diagnosed with clinical evaluation, it has been stated in the literature that diagnosis in as many as $15 \%$ of cases can be challenging. In uncertain cases, imaging can help determine diagnosis.

METHODS: Present study included 20 cases where diagnosis could not be made with certainty and magnetic resonance imaging (MRI) was performed. MR images were examined for tunical rupture and accompanying pathologies. When rupture was observed, localization and length of rupture were noted. All patients underwent degloving surgery. All imaging findings were compared to surgical findings.
\end{abstract}

RESULTS: MRI revealed 19 tunical ruptures. In I case, hematoma was seen with no sign of penile fracture. No urethral injuries were found. All MRI findings were confirmed during surgery.

CONCLUSION: Performing MRI in clinically equivocal cases can provide crucial data to make precise diagnosis and improve patient management.

Keywords: Magnetic resonance imaging; penile fracture; radiology.

\section{INTRODUCTION}

Penile fracture is a rare, traumatic rupture of the tunica albuginea that most often occurs during sexual intercourse, but sometimes occurs during masturbation or in fall on the erect penis. ${ }^{[]]}$Generally, diagnosis of fracture is based on history and physical examination. Classic presentation may include cracking sensation, severe penile pain associated with shaft deviation, ecchymosis, and palpable defect in the tunica albuginea ${ }^{[2]}$ Nevertheless, this description is not pathognomonic for rupture of corporeal bodies. Atypical cases may occur, and in I study, history and physical examination were inaccurate in $15 \%$ of patients with suspected penile fracture. ${ }^{[3]}$ Dif-

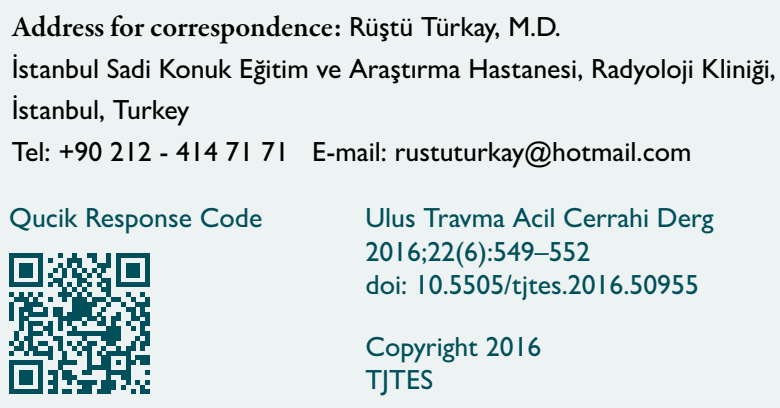

ferential diagnosis of penile fracture includes injury to dorsal penile vessels and extra-albugineal hematoma. ${ }^{[4]}$ Differentiating these diagnoses from penile fracture is important clinically because fractures require surgical intervention, whereas other conditions can generally be managed conservatively. Penile fracture is a surgical emergency. If not treated immediately, complications such as chronic pain, penile curvature, Peyronie's plaque formation, arteriovenous fistula, or erectile dysfunction have been seen in $10 \%$ to $53 \%$ of patients. ${ }^{[5]}$ In the management of clinically uncertain penile fracture cases, imaging studies can be helpful to clarify the diagnosis.

The present study is an evaluation of the contribution of magnetic resonance imaging (MRI) to clinically equivocal penile fracture cases.

\section{MATERIALS AND METHODS}

The institutional review board of Dr. Sadi Konuk Training and Research Hospital approved this study. The Declaration of Helsinki protocols were followed. Written informed consent was obtained from each participant. There were 20 patients (aged 19-60 years with mean age of 39.5 years) in the study whose diagnosis could not be made based only 
on clinical findings. MRI was performed to assess diagnosis of penile fracture. Blunt penile trauma occurred during erection in all patients. History revealed that etiology was sexual intercourse activity in 12 patients. For the remaining 8 patients, causes were rolling over in bed $(n=3)$ and masturbation $(n=5)$. Delay between injury and management ranged from 4 to 46 hours (mean: 25 hours). Acute penile pain was present in all cases. Cracking sound was reported by 8 patients. Urethral injury was not detected in any of the patients. In all cases there was sudden detumescence after injury. Physical examination revealed grossly ecchymotic penis with normal glans and no palpable tunical defect. Ecchymosis involved the scrotum in 2 patients and the pubic area in I other. Penile shaft deviation was found in 8 cases. MR imaging was used to evaluate need for immediate surgery in all patients.

All cases underwent degloving surgery. In I case, careful dissection revealed avulsion of superficial dorsal vein was source of bleeding and no tunical defect was observed. No significant intraoperative or immediate postoperative complications were noted. Patients were discharged I or 2 days postoperatively.
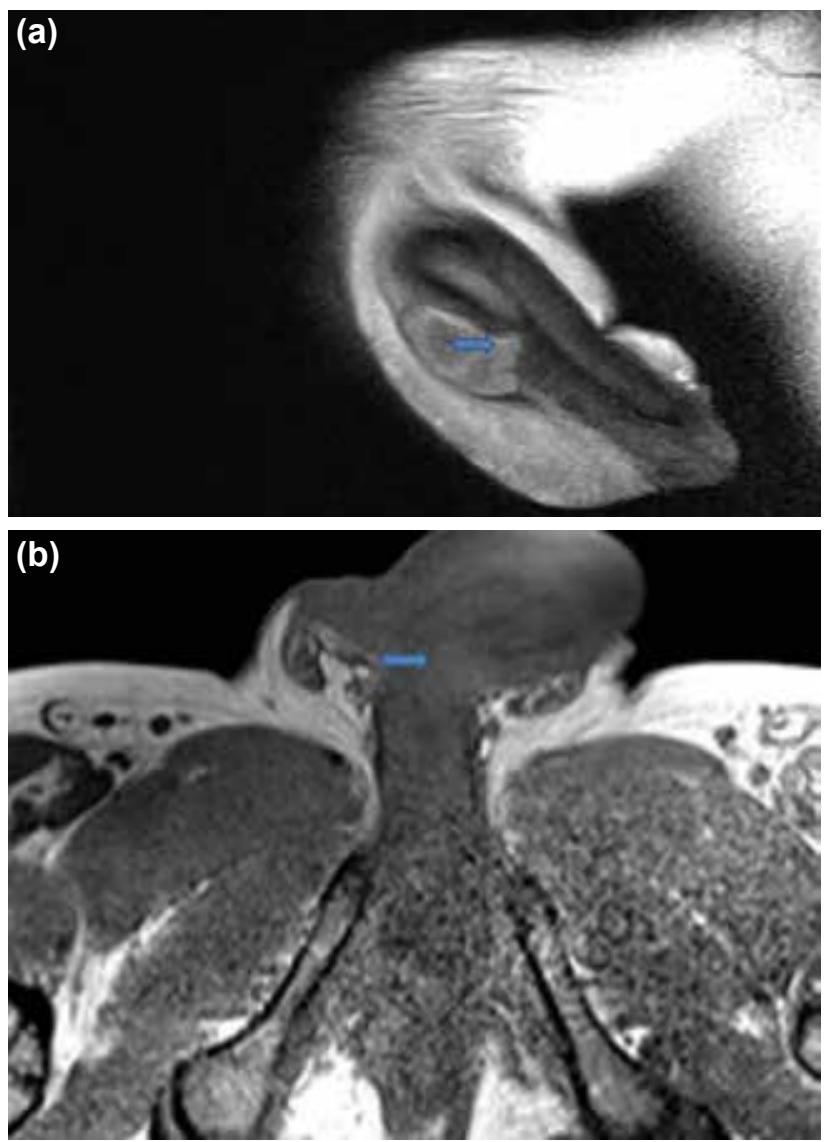

Figure 1. (a) T2-weighted sagittal magnetic resonance image. Arrow shows the disruption of low signal line of tunica albuginea (b) Same patient with T1-weighted axial magnetic resonance image. Arrow indicates fracture of tunica.

\section{MR Imaging}

MR sequences: All MR imaging was performed with 3T Magnetom Verio (Siemens, AG, Berlin, Germany). High resolution, thin slice $(3 \mathrm{~mm})$ images of the penis were taken in the anatomical position. T2-weighted spin echo sequences in 3 orthogonal planes and TI in axial plane were used. Contrast material was not used.

\section{Findings}

In 19 of 20 patients, MRI depicted disruption of low-signalintensity tunica albuginea, which is generally well seen on both T2- and TI-weighted images (Figs. Ia, b). Location of tears was noted according to distance from corona. We observed II right and 8 left corpus cavernosum tears. Extent of tunical tears was measured (range: $6.5-14 \mathrm{~mm}$; mean $9 \mathrm{~mm}$ ). In I patient, no tunical laceration was visible on MRI, only large hematoma in shaft of the penis (Figs. 2a, b). Underlying cause was not evident. No signs of urethral injury were observed in any $M R$ images.

\section{RESULTS}

Total of 19 of 20 clinically equivocal patients were diagnosed
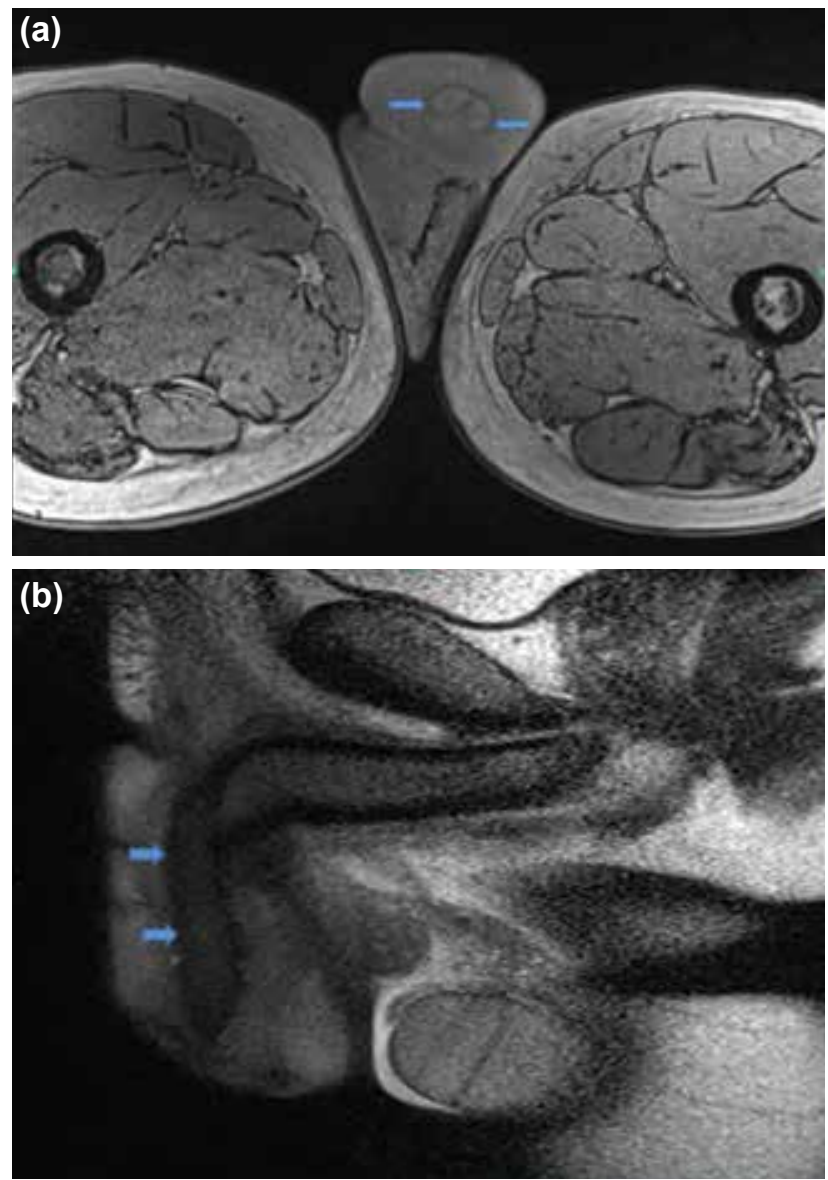

Figure 2. (a) Sagittal T2-weighted magnetic resonance images of intact tunica albuginea (arrows). (b) Axial T1-weighted magnetic resonance image of intact tunica albuginea (arrows). 
as having penile fracture based on MRI findings. MRI depicted intact tunica albuginea in I patient and thereby did not support clinical prediagnosis of penile fracture. Strong clinical suspicion prompted surgery; however, which revealed dorsal vein rupture. There were no findings of urethral injury in the study. All MRI findings were confirmed during surgery.

\section{DISCUSSION}

Penile fracture is rupture of $I$ or both of the tunica albuginea, the fibrous covering that envelops the corpora cavernosa in the erect penis. When erect, thick tunica albuginea become thin and fracturable. Penile fracture usually occurs during sexual intercourse or masturbation. Rarely, cause may be blunt force to erect penis such as in fall from bed or during a fight. Penile rupture can usually be diagnosed based solely on history and physical examination findings; however, in equivocal cases, radiological examinations should be performed to confirm diagnosis as well as to determine precise localization and extent of tunical rupture. ${ }^{[6]}$ Cracking sound has been reported in $43 \%$ of cases, palpable defect seen in $55 \%$ of cases, and penile deviation has been observed in $83 \%$ of cases. On basis of history and physical examination alone, rate of misdiagnosis can be as high as $15 \%{ }^{[3,6]}$ Differential diagnosis of penile fracture includes superficial dorsal vein rupture, deep dorsal vein rupture, dorsal penile artery avulsion, and nonspecific dartos bleeding. ${ }^{[4,7]}$ Differentiating these diagnoses from penile fracture is important clinically because fractures require surgical intervention, whereas dorsal penile vessel injuries and extra-albugineal hematomas can generally be managed conservatively. All entities may cause penile pain and swelling. Extraalbugineal hematoma, for example, is more common with trauma to flaccid penis, whereas fractures usually occur when the penis is erect. ${ }^{[6]}$ Rupture of dorsal penile vessels tends to occur with trauma to erect penis, but detumescence tends to be delayed, unlike instance of fracture. Fractures also tend to present with palpable defects of cavernosa that are usually painful on palpation, a finding usually not present with more superficial injury. When diagnosis of penile fracture based on history and physical examination alone is not possible, imaging studies may be useful to clarify diagnosis. Imaging modalities such as cavernosography, ultrasonography (US), and MRI can be used to positively identify penile fracture. Cavernosography is invasive and painful imaging modality that has significant false-negative results. ${ }^{[8]}$ US can help detect defects in the tunica albuginea in the majority of patients (although false-negative results do occur), ${ }^{[9]}$ and can also depict hematoma and injuries of the corpus spongiosum and urethra. In difficult cases, handicap of US is lack of tissue contrast, especially in detumescent pendulous part of the penis. MRI is superior to US in soft tissue imaging. Fedel et al. compared US and MR imaging and found that US was not helpful, whereas MR imaging was much more informative in penile fracture cases. ${ }^{[10]}$ Furthermore, US is user-dependent modality, and experience in penile sonography is not common among radiologists. MRI can also depict urethral injury, whereas US is not quite capable of showing injury to urethra. ${ }^{\left[{ }^{11}\right]}$ For these reasons, we prefer MR imaging in evaluation of this type of clinically challenging case.

The key finding in penile fracture is disruption of low-signalintensity tunica albuginea, which can be easily seen on both T2- and TI-weighted images (Figs. Ia, b). Although contrast resolution is better with T2-weighted sequences, TI-weighted sequences may help detect more subtle fractures. One study reported that defect in the tunica albuginea was clearly seen with $\mathrm{TI}$-weighted sequences in 3 of 4 patients. ${ }^{\left[{ }^{\prime I}\right]} \mathrm{A}$ possible explanation is that acute hematoma may have low signal intensity on T2-weighted images and thereby mimic intact tunica albuginea. ${ }^{\left[{ }^{I I]}\right.}$ In present series, all tunical tears were visible in T2-weighted images. One possible explanation for this may be that Uder et al. used IT MRI in that study, while we used 3T MRI scan, which has higher resolution and thereby provides greater detail than IT MRI. In another study, MR imaging helped identify 3 cases of painful post-traumatic hematoma (either intracavernosal or outside the tunica albuginea) without disruption of the tunica albuginea, thereby avoiding surgical exploration. ${ }^{[12]}$ Rupture of the dorsal vein of the penis is a rare condition that mimics acute fracture and should be distinguished from rupture with MR imaging. ${ }^{[2]}$ In the present series, we had I case of dorsal vein rupture, which was confirmed surgically. MR images revealed subcutaneous hematoma with intact tunica albuginea. Although MRI did not illustrate dorsal vein rupture, it allowed us to correctly rule out diagnosis of penile rupture, which is a surgical emergency entity.

In the literature, several groups have found that accurate delineation of the site of fracture can enable surgeon to use a small focal incision, ${ }^{[1,12]}$ rather than the extensive subcoronal degloving approach used in the past and which probably has a higher prevalence of complications. ${ }^{[13]}$ In the present series of clinically equivocal penile fracture cases, MRI indicated precise location and extent of defect in the tunical albuginea.

Although MRI is expensive and needs additional apparatus, it is an informative tool for evaluating and documenting penile fracture and it also improves the management plan. In equivocal cases, $M R$ imaging may provide additional data to make confident diagnosis. Furthermore, in small number of patients, diagnosis of rupture may confidently be excluded, avoiding unnecessary surgical exploration. With knowledge of exact location of tunical rupture, MRI may also help surgeons keep incision small and thereby contribute to decreasing possible complications of surgery.

Conflict of interest: None declared.

\section{REFERENCES}

1. Kirkham AP, Illing RO, Minhas S, Minhas S, Allen C. MR imaging of nonmalignant penile lesions. Radiographics 2008;28(3):837-53. Crossref

2. Nomura JT, Sierzenski PR. Ultrasound diagnosis of penile fracture. J Emerg Med 2010;38:362-5. Crossref 
3. Beysel M, Tekin A, Gürdal M, Yücebaş E, Sengör F. Evaluation and treatment of penile fractures: accuracy of clinical diagnosis and the value of corpus cavernosography. Urology 2002;60:492-6. Crossref

4. Feki W, Derouiche A, Belhaj K, Ouni A, Ben Mouelhi S, Ben Slama $\mathrm{MR}$, et al. False penile fracture: report of 16 cases. Int J Impot Res 2007;19:471-3. Crossref

5. Gedik A, Kayan D, Yamiş S, Yllmaz Y, Bircan K. The diagnosis and treatment of penile fracture: our 19-year experience. Ulus Travma Acil Cerrahi Derg 2011;17:57-60. Crossref

6. Karadeniz T, Topsakal M, Ariman A, Erton H, Basak D. Penile fracture: differential diagnosis, management and outcome. Br J Urol 1996;77:27981. Crossref

7. De Rose AF, Giglio M, Carmignani G. Traumatic rupture of the corpora cavernosa: new physiopathologic acquisitions. Urology 2001;57:319-22.

8. Grosman H, Gray RR, St Louis EL, Casey R, Keresteci AG, Elliott DS.
The role of corpus cavernosography in acute "fracture" of the penis. Radiology 1982;144:787-8. Crossref

9. Dierks PR, Hawkins H. Sonography and penile trauma. J Ultrasound Med 1983;2:417-9.

10. Fedel M, Venz S, Andreessen R, Sudhoff F, Loening SA. The value of magnetic resonance imaging in the diagnosis of suspected penile fracture with atypical clinical findings. J Urol 1996;155:1924-7. Crossref

11. Uder M, Gohl D, Takahashi M, Derouet H, Defreyne L, Kramann B, et al. MRI of penile fracture: diagnosis and therapeutic follow-up. Eur Radiol 2002;12:113-20. Crossref

12. Abolyosr A, Moneim AE, Abdelatif AM, Abdalla MA, Imam HM. The management of penile fracture based on clinical and magnetic resonance imaging findings. BJU Int 2005;96:373-7. Crossref

13. Morris SB, Miller MA, Anson K. Management of penile fracture. J R Soc Med 1998;91:427-8.

\section{ORIJIINAL ÇALIŞMA - ÖZET}

\section{Klinik olarak tanı konulamayan penil fraktür olgularına MR görüntülemenin katkısı \\ Dr. Rüştü Türkay, ${ }^{1}$ Dr. Mustafa Gürkan Yenice, ${ }^{2}$ Dr. Sema Aksoy, ${ }^{1}$ Dr. Gökhan Şeker, ${ }^{2}$ \\ Dr. Selçuk Şahin,, ${ }^{2}$ Dr. Ercan İnci, ${ }^{1}$ Dr. Volkan Tuğcu, ${ }^{2}$ Dr. Ali İhsan Taşcı ${ }^{2}$}

${ }^{1}$ İstanbul Dr. Sadi Konuk Eğitim ve Araştırma Hastanesi, Radyoloji Kliniği, İstanbul
${ }^{2} \mid$ stanbul Dr. Sadi Konuk Eğitim ve Araştırma Hastanesi, Üroloji Kliniği, İstanbul

AMAÇ: Penil fraktür tunika albugineada oluşan rüptür olup acil cerrahi müdahale gerektirir. Olguların çoğunluğu klinik değerlendirme ile tanı alabilirse de literatürde belirtildiği gibi \% 5 gibi bir oranda sadece klinik ile tanı konulmasında zorlanılabilir. Bu durumda görüntüleme tanı konmasında yardımcı olabilir.

GEREÇ VE YÖNTEM: Bizim çalışmamızda tanısı klinik olarak konulamamış 20 hastaya manyetik rezonans (MR) görüntüleme yapıldı. Manyetik rezonans görüntülerinde tunikal bütünlük kaybı ve eşlik edebilecek diğer patolojiler araştırıldı. Rüptür izlenen olgularda bu rüptürün lokalizasyonu ve uzunluğu kaydedildi. Hastaların tamamı ameliyat edildi. Görüntüleme bulguları operasyon bulguları ile karşılaştırıldı.

BULGULAR: Manyetik rezonans görüntülemede 19 tunikal rüptür tanımlandı. Bir olguda sadece hematom görüntülenebilmiş olup tunikal rüptür lehine bir bulgu saptanmadı. Hiçbir olguda üretral yaralanma gözlenmedi. Görüntüleme bulgularının tamamı operasyon bulguları ile doğrulandı. TARTIŞMA: Klinik olarak tanısında zorlanılan penil fraktür olgularında MR görüntüleme tanının doğrulukla ve güvenle konmasında kritik bilgiler sağlayabilir.

Anahtar sözcükler: Manyetik rezonans görüntüleme; penil fraktür; radyoloji. 